\title{
Burkholderia acidipaludis sp. nov., aluminium- tolerant bacteria isolated from Chinese water chestnut (Eleocharis dulcis) growing in highly acidic swamps in South-East Asia
}

Correspondence
Michio Sunairi
sunairi.michio@nihon-u.ac.jp

\author{
Tomoko Aizawa, ${ }^{1}$ Nguyen Bao Ve, ${ }^{2}$ Pisoot Vijarnsorn, ${ }^{3}$ \\ Mutsuyasu Nakajima ${ }^{1,4}$ and Michio Sunairi ${ }^{1}$ \\ ${ }^{1}$ Department of Applied Biological Sciences, College of Bioresource Sciences, Nihon University, \\ 1866 Kameino, Fujisawa, Kanagawa 252-0880, Japan \\ ${ }^{2}$ Department of Crop Science, College of Agriculture, Can Tho University, 3/2 Street, Can Tho, \\ Vietnam \\ ${ }^{3}$ Royal Acid Sulfate Soil Improvement Experiment Station, Nakhon Nayok 26110, Thailand \\ ${ }^{4}$ Environmental Program, Nihon University Advanced Research Institute for the Sciences and \\ Humanities, 12-5 Goban-cho Chiyoda, Tokyo 102-8251, Japan
}

Yabuuchi et al. (1992) created the genus Burkholderia by the transfer of seven species from Pseudomonas, with Burkholderia cepacia as the type species. During the course of a study to develop bioremediation measures for actual acid sulfate soils (AASS; Aizawa et al., 2008; Sasaki et al.,

Abbreviation: AASS, actual acid sulfate soil.

The GenBank/EMBL/DDBJ accession numbers for the $16 \mathrm{~S}$ rRNA gene sequences of strains $\mathrm{SA33}^{\top}$ and $7 \mathrm{A078}$ are $\mathrm{AB} 513180$ and AB513181.

A scanning electron micrograph of cells of strain SA33 ${ }^{\top}$, SDS-PAGE profiles of whole-cell extracts and physiological characteristics and fatty acid compositions of the novel strains and type strains of related species are available as supplementary material with the online version of this paper.
2008), we isolated a number of bacteria associated with plants growing in highly acidic aquatic environments ( $\mathrm{pH}$ 2-4) of AASS in South-east Asia (Aizawa et al., 2007, 2010; Kimoto et al., 2010). In this present study, we characterized two $\mathrm{pH}$-neutralizing bacteria, strain $\mathrm{SA} 33^{\mathrm{T}}$, isolated from Chinese water chestnut (Eleocharis dulcis) growing in highly acidic swamps ( $\mathrm{pH} 2-4)$ in AASS areas in Vietnam, and 7A078, isolated from E. dulcis growing in similar areas in Thailand. By a polyphasic approach, including 16S rRNA gene sequence analysis, DNA-DNA hybridization, whole-cell protein analysis, fatty acid methyl ester analysis and phenotypic and biochemical characterization, the strains were shown to be affiliated with the genus Burkholderia. The data obtained suggest that the strains represent a novel species of the genus Burkholderia. 
A number of bacteria were isolated from plants of $E$. dulcis by using one-tenth-strength tryptic soy (1/10 TS) agar plates [3.0 g tryptic soy broth $\mathrm{l}^{-1}$ (Difco) solidified with

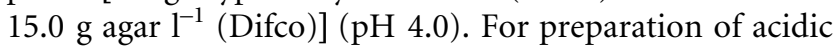
plates, double-strength medium and $3 \%$ agar solution were autoclaved separately and mixed after autoclaving to prevent hydrolysis of the agar. Among these isolates, $\mathrm{pH}$ neutralizing bacteria were selected on the basis of neutralization of $1 / 10$ TS liquid medium ( $\mathrm{pH} 4.0$ ), determined by measuring the $\mathrm{pH}$ of culture supernatants after a 3-day cultivation period. Strains $\mathrm{SA} 33^{\mathrm{T}}$ and $7 \mathrm{~A} 078$ were isolated from an aquatic stem sample collected in Vietnam and internal tissues of a surface-sterilized root sample collected in Thailand, respectively. Strains SA33 ${ }^{\mathrm{T}}$ and 7A078 formed round, smooth, convex, pale-yellow colonies with entire margins on 1/10 TS ( $\mathrm{pH} 4.0$ ) agar plates. Both strains showed good growth on these plates at $17-37{ }^{\circ} \mathrm{C}$, with optimum growth at $28-32{ }^{\circ} \mathrm{C}$, but did not grow at 5 or $42{ }^{\circ} \mathrm{C}$. The strains showed good growth at $\mathrm{pH} 3-8$, with optimum growth at $\mathrm{pH} 4-7$, but no or little growth below $\mathrm{pH} 2$ or above $\mathrm{pH} 9$ when cultured at $30{ }^{\circ} \mathrm{C}$ for 5 days. Growth was as good on TS ( $\mathrm{pH} 4.0)$ agar plates as on 1/10 TS ( $\mathrm{pH} 4.0)$ agar plates. Growth under anaerobic conditions was determined after 5 days of incubation at $30{ }^{\circ} \mathrm{C}$ in an AnaeroPack (Mitsubishi Gas Chemical Co., Ltd). The strains showed good growth on $1 /$ 10 TS ( $\mathrm{pH} 4.0$ ) agar plates under aerobic conditions but not under anaerobic conditions. Cells grown on 1/10 TS ( $\mathrm{pH} 4.0$ ) agar plates were Gram-negative (Ryu, 1938), nonendospore-forming and non-motile. Their morphology was observed by scanning electron microscopy, as described previously (Aizawa et al., 2010). The cells were irregular rods, $0.6-0.7 \mu \mathrm{m}$ wide and 1.3-1.7 $\mu \mathrm{m}$ long, when the organisms were cultured on 1/10 TS ( $\mathrm{pH} 4.0)$ agar plates at $28{ }^{\circ} \mathrm{C}$ for 3 days (Supplementary Fig. S1, available in IJSEM Online).

The 16S rRNA genes of the strains were amplified by PCR using universal primers (Tamura \& Hatano, 2001), and nearly complete $16 \mathrm{~S}$ rRNA gene nucleotide sequences were determined. These sequences showed high similarity to species within the genus Burkholderia. The 16S rRNA gene sequence similarities of strain SA33 ${ }^{\mathrm{T}}$ to $7 \mathrm{~A} 078$, Burkholderia kururiensis $\mathrm{KP}^{2} 3^{\mathrm{T}}$, B. sacchari LMG $19450^{\mathrm{T}}$ and B. tuberum STM $678^{\mathrm{T}}$ were $100,97.3,97.1$ and $97.0 \%$, respectively. The phylogenetic relationship with closely related species was determined by using MEGA version 4 (Tamura et al., 2007) and the PHYLIP 3.65 package (Felsenstein, 2005) after multiple sequence alignments performed with CLUSTAL_X (Thompson et al., 1997). Evolutionary distances were computed as described by Jukes \& Cantor (1969). Phylogenetic trees were reconstructed by using the maximum-parsimony (Kluge \& Farris, 1969), maximumlikelihood (Felsenstein, 1981) and neighbour-joining (Saitou \& Nei, 1987) methods. The reliability of these tree topologies was evaluated by bootstrap analysis with 1000 replicates (Felsenstein, 1985). The phylogenetic trees reconstructed by these three methods showed that strains
SA $33^{\mathrm{T}}$ and 7A078 belonged to the genus Burkholderia, in which these strains formed a cluster with some Burkholderia species isolated from plants and soil, Burkholderia tuberum (Vandamme et al., 2002), B. mimosarum (Chen et al., 2006) and B. nodosa (Chen et al., 2007) isolated from mimosa, Burkholderia silvatlantica (Perin et al., 2006), B. unamae (Caballero-Mellado et al., 2004) and B. tropica (Reis et al., 2004) isolated from maize and sugar cane, Burkholderia heleia (Aizawa et al., 2010) from Chinese water chestnut, Burkholderia sacchari (Brämer et al., 2001) isolated from soil of a sugar cane plantation and B. kururiensis M130 (Caballero-Mellado et al., 2007) isolated from the root of a rice plant growing in Brazil (Baldani et al., 1997; Weber et al., 1999), as well as Burkholderia ferrariae (Valverde et al., 2006), isolated from iron ore. The phylogenetic tree constructed by using the neighbour-joining method is shown in Fig. 1. Although the strains showed a high degree of $16 \mathrm{~S}$ rRNA gene sequence similarity to established species of the genus, they formed a separate line of descent in the phylogenetic cluster of the genus (Fig. 1). Stackebrandt \& Goebel (1994) pointed out that a high degree of 16S rRNA gene sequence similarity ( $97 \%$ or higher) is of limited value for differentiating species and that DNA-DNA hybridization studies must be performed to determine species affiliation under these circumstances. Therefore, we performed DNA-DNA hybridization on these strains and their neighbours on the phylogenetic tree by using the microplate hybridization method (Ezaki et al., 1988, 1989) as described by Tamura et al. (1999) with the modification that the hybridization temperature was $51{ }^{\circ} \mathrm{C}$. The DNA-DNA relatedness value of strain $\mathrm{SA} 33^{\mathrm{T}}$ to $7 \mathrm{~A} 078$ was $90 \%$, which is higher than the recommended threshold value $(70 \%)$ for the delineation of genomic species (Wayne et al., 1987). Strain SA33 ${ }^{\mathrm{T}}$ exhibited relatively low levels of DNA-DNA relatedness with respect to B. kururiensis JCM $10599^{\mathrm{T}}$ (47\%), B. sacchari LMG $19450^{\mathrm{T}}(46 \%)$ and B. tuberum LMG $21444^{\mathrm{T}}(45 \%)$, indicating that strain $\mathrm{SA} 33^{\mathrm{T}}$ was not related to them at the species level. These data suggest that strains SA33 ${ }^{\mathrm{T}}$ and $7 \mathrm{~A} 078$ represent a novel species of the genus Burkholderia.

Additionally, strains $\mathrm{SA} 33^{\mathrm{T}}$ and 7A078 could be distinguished from closely related species of Burkholderia in the phylogenetic trees (Fig. 1) on the basis of physiological characteristics (Supplementary Table S1). Strains SA33 ${ }^{\mathrm{T}}$ and 7A078 did not show positive results in acetylene reduction experiments (Burris, 1972) using Winogradsky's nitrogen-free mineral soft-gel medium containing $1 \%$ mannitol (Hashidoko et al., 2002), whereas the closely related type strains in the phylogenetic trees (Fig. 1), except B. sacchari LMG $19450^{\mathrm{T}}$ and B. ferrariae LMG $23612^{\mathrm{T}}$, were positive. Interestingly, strains $\mathrm{SA} 33^{\mathrm{T}}$ and $7 \mathrm{~A} 078$, as well as B. ferrariae LMG $23612^{\mathrm{T}}$, gave positive results in the PCR assay for nifH (Caballero-Mellado et al., 2007), whereas $B$. sacchari LMG $19450^{\mathrm{T}}$ gave a negative result; the results for B. sacchari LMG $19450^{\mathrm{T}}$ and B. ferrariae LMG $23612^{\mathrm{T}}$ were in accordance with a previous report (Caballero-Mellado et al., 2007). Further study might be necessary to determine 


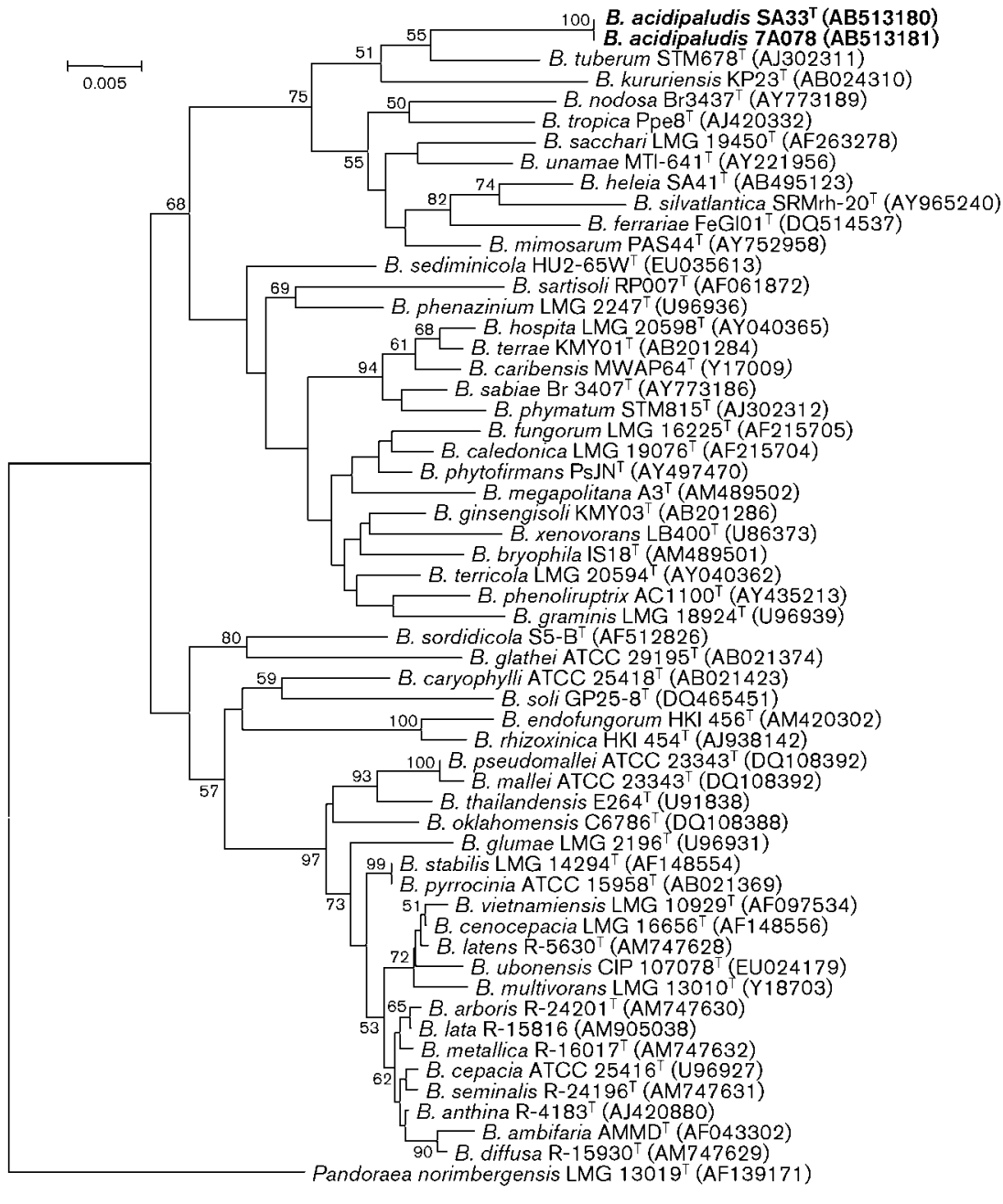

Fig. 1. Neighbour-joining tree based on nearly complete 16S rRNA gene sequences (positions 97-1417 of the Escherichia coli 16S rRNA gene), showing the positions of strains $\mathrm{SA} 33^{\mathrm{T}}$ and $7 \mathrm{~A} 078$ among species of the genus Burkholderia. Numbers at branch nodes are percentages based on 1000 resamplings; only values $\geqslant 50 \%$ are given. The sequence of Pandoraea norimbergensis LMG $13019^{\top}$ was used as an outgroup. Bar, 0.005 substitutions per nucleotide position. the diazotrophy of these nifH-positive strains. Strains SA $33^{\mathrm{T}}$ and 7A078 could grow in the presence of $5 \mathrm{mM}$ $\mathrm{AlCl}_{3}$ in $0.1 \%$ BactoTryptone (Difco) adjusted to $\mathrm{pH} 3.5$ with sulfuric acid, whereas the closely related type strains except those of B. tropica and B. unamae did not. Standard physiological tests were carried out according to the methods described previously (Smibert \& Krieg, 1994). Acid production from carbon sources, enzyme activities and resistance to antibiotics were assessed by using the API $50 \mathrm{CH}$ system, the API ZYM and API 20E systems and the ATB VET system (bioMérieux), respectively, according to the manufacturer's instructions. Utilization of various substrates as sole carbon sources was tested by using Biolog GN2 microplates in accordance with the manufacturer's instructions. Analyses of DNA G $+\mathrm{C}$ content and cellular fatty acids were performed as described by Tamura et al. (1994). The major isoprenoid quinone was determined as described previously (Aizawa et al., 2010). The DNA $\mathrm{G}+\mathrm{C}$ content of strains $\mathrm{SA} 33^{\mathrm{T}}$ and $7 \mathrm{~A} 078$ was $64 \mathrm{~mol} \%$. The major fatty acids of both strains grown on $1 /$ 10 TS agar plates containing $1 \%$ glucose $\left(\mathrm{pH} \mathrm{5.0)}\right.$ at $28{ }^{\circ} \mathrm{C}$ for 3 days were $\mathrm{C}_{16: 0}, \mathrm{C}_{18: 1} \omega 7 c$ and $\mathrm{C}_{17: 0}$ cyclo (Supplementary Table S2); similar patterns were obtained from cells of the type strains of closely related species of the genus. The major isoprenoid quinone of the strains was determined to be Q-8, as is the case for other species of the genus Burkholderia (Yamada et al., 1982; Zhang et al., 2000; Yang et al., 2006; Valverde et al., 2006; Aizawa et al., 2010).

Whole-cell protein extracts were prepared from strains SA33 ${ }^{\mathrm{T}}$ and 7A078 and the type strains of several related species and analysed by SDS-PAGE, as described previously (Pot et al., 1994), and the results are shown in Supplementary Fig. S2. The newly isolated strains showed protein profiles that were clearly different from those of type strains of related Burkholderia species. Since it is well known that bacteria with identical or very similar protein patterns possess high genome similarity (Vandamme et al., 1996), these SDS-PAGE results support the notion that strains $\mathrm{SA} 33^{\mathrm{T}}$ and $7 \mathrm{~A} 078$ represent a novel aluminiumtolerant Burkholderia species.

Therefore, based on the physiological, biochemical, chemotaxonomic and molecular-genetic results described above, strains $\mathrm{SA} 33^{\mathrm{T}}$ and 7A078 were concluded to represent a novel species of the genus Burkholderia, for which the name Burkholderia acidipaludis sp. nov. is proposed. 


\section{Description of Burkholderia acidipaludis sp. nov.}

Burkholderia acidipaludis [a.ci'di.pa.lu'dis. N.L. adj. acidus - a -um (from L. n. acidum) acid; L. gen. n. paludis of a swamp; N.L. gen. n. acidipaludis of an acidic swamp].

Cells are Gram-negative, strictly aerobic, non-spore-forming, non-motile rods $(0.6-0.7 \times 1.3-1.7 \mu \mathrm{m})$. Colonies are smooth, round, convex and pale-yellow with entire margins after 3 days of cultivation at $32{ }^{\circ} \mathrm{C}$ on $1 / 10 \mathrm{TS}(\mathrm{pH} 4.0)$ agar plates. Growth occurs at $17-37{ }^{\circ} \mathrm{C}$ with optimum growth at $28-32{ }^{\circ} \mathrm{C}$. The $\mathrm{pH}$ range for growth is $3-8$, with optimum growth at $\mathrm{pH} 4-7$. Positive for hydrolysis of Tweens 20, 40 and 60. Positive for activities of oxidase, catalase, acid and alkaline phosphatases, esterase (C4), esterase lipase (C8), leucine arylamidase, naphthol-AS-BI-phosphohydrolase and urease and reduction of nitrate to nitrite, but negative for hydrolysis of DNA and gelatin, activities of lipase (C4), trypsin, $\alpha$-chymotrypsin, $\alpha$-galactosidase, $\beta$-glucuronidase, $\alpha$-glucosidase, $N$-acetyl- $\beta$-glucosaminidase, $\alpha$-mannosidase, $\alpha$-fucosidase and proteinase, indole production and reduction of nitrate to nitrogen gas (API ZYM, API 20E and API 20NE systems). Positive for acid production from glycerol, D- and L-arabinose, D-ribose, D-xylose, D-adonitol, Dgalactose, D-glucose, D-fructose, D-mannose, L-rhamnose, inositol, D-mannitol, D-sorbitol, cellobiose, maltose, lactose, D-lyxose, D-tagatose, D- and L-fucose and D- and L-arabitol, but negative for acid production from methyl $\beta$-Dxylopyranoside, methyl $\alpha$-D-mannopyranoside, methyl $\alpha$ D-glucopyranoside, amygdalin, arbutin, salicin, melibiose, sucrose, trehalose, inulin, melezitose, raffinose, starch, xylitol, turanose, potassium gluconate and potassium 5ketogluconate (API 50CH). Positive for utilization of Tweens 40 and $80, N$-acetyl-D-glucosamine, adonitol, L-arabinose, D-arabitol, $i$-erythritol, D-fructose, L-fucose, Dgalactose, $\alpha$-D-glucose, myo-inositol, D-mannitol, D-mannose, D-psicose, L-rhamnose, D-sorbitol, pyruvic acid methyl ester, succinic acid monomethyl ester, D-galacturonic acid, D-gluconic acid, D-glucosaminic acid, $\beta$-hydroxybutyric acid, p-hydroxyphenylacetic acid, DL-lactic acid, sebacic acid, succinic acid, bromosuccinic acid, L-alanine, Lasparagine, L-aspartic acid, L-glutamic acid, L-histidine, hydroxy-L-proline, L-phenylalanine, L-proline, L-pyroglutamic acid, L-threonine, DL-carnitine, urocanic acid, phenylethylamine and glycerol as sole carbon sources, but negative for utilization of $\alpha$-cyclodextrin, $N$-acetyl-D-galactosamine, gentiobiose, lactose, lactulose, maltose, melibiose, methyl $\beta$ D-glucoside, raffinose, sucrose, turanose, xylitol, cis-aconitic acid, citric acid, D-glucuronic acid, itaconic acid, $\alpha$ ketoglutaric acid, $\alpha$-ketovaleric acid, malonic acid, Dsaccharic acid, glucuronamide, glycyl L-aspartic acid, glycyl L-glutamic acid, L-ornithine, inosine, thymidine, putrescine, 2-aminoethanol and 2,3-butanediol (Biolog GN2 Microplate). Resistant to $\left(\mu \mathrm{g} \mathrm{ml}{ }^{-1}\right)$ penicillin (0.25), amoxicillin (4), amoxicillin/clavulanic acid (4/2), oxacillin (2), cephalothin (8), cefoperazone (4), chloramphenicol (8), erythromycin (1), lincomycin (2), pristinamycin (2), tylosin (2), sulfamethizole (100), nitrofurantoin (25), fusidic acid (2), rifampicin (4) and metronidazole (4), but sensitive to streptomycin (8), spectinomycin (64), kanamycin (8), apramycin (16), tetracycline (4), doxycycline (4), gentamicin (4), colistin (4), co-trimoxazole (2/38) and oxolinic acid (2) (ATB VET). The major isoprenoid quinone is Q-8. The predominant cellular fatty acids are $\mathrm{C}_{16: 0}, \mathrm{C}_{18: 1} \omega 7 c$ and $\mathrm{C}_{17: 0}$ cyclo. The DNA G+C content of the two known strains is $64 \mathrm{~mol} \%$.

The type strain, SA33 ${ }^{\mathrm{T}}\left(=\right.$ NBRC $101816^{\mathrm{T}}=$ VTCC-D6- $6^{\mathrm{T}}$ ), was isolated from an aquatic plant, Eleocharis dulcis, that grows luxuriantly in a highly acidic swamp $(\mathrm{pH} 3)$ in an AASS area in Vietnam. Strain 7A078 (=NBRC 103872 = BCC 36999), isolated from a similar habitat in Thailand, is a reference strain.

\section{Acknowledgements}

We are most grateful to S. Sasaki for giving us the opportunity to conduct this research. We also thank $\mathrm{H}$. Uchiyama for identification of E. dulcis, I. Hasegawa, H. Sumida, A. Noguchi, M. Kawahigasi, M. N. Do, H. Le and N. H. Ngo for help in collecting the samples and M. Ohkuma and S. Noda for advice on the acetylene reduction assay. We acknowledge T. Asai, T. Morita, M. Shimizu, G. Hashimoto, K. Kimoto, T. Taguti and various other members of our laboratories for their technical assistance and encouragement. We acknowledge D. V. Hop at the VTCC, P. Rattanawaree at the BCC and K. Suzuki, Y. Nakagawa and Y. Muramatsu at the NBRC for deposit of the isolates as well as M. Hyoudou, M. Kogure, N. Murayama and N. Sekino at the Integrated Research Institute for their technical assistance. This study was partly supported by a grant from the Institute for Fermentation (IFO; Osaka, Japan) and by grants-in-aid for scientific research (nos 21780300 and 20580365) from the Japan Society for Promotion of Science. T.A. was supported by funding from the Center of Excellence in 21st Century Projects and the High-Tech Research Center Projects of the Ministry of Education, Culture, Sports, Science, and Technology of Japan.

\section{References}

Aizawa, T., Nguyen, B. V., Kimoto, K., Iwabuchi, N., Sumida, H., Hasegawa, I., Sasaki, S., Tamura, T., Kudo, T. \& other authors (2007). Curtobacterium ammoniigenes sp. nov., an ammonia-producing bacterium isolated from plants inhabiting acidic swamps in actual acid sulfate soil areas of Vietnam. Int J Syst Evol Microbiol 57, 1447-1452.

Aizawa, T., Nguyen, B. V., Vijarnsorn, P., Kimoto, K., Sasaki, S., Nakajima, M. \& Sunairi, M. (2008). Application of symbiotic bacteria isolated from plants adapted to actual acid sulfate soil. In Development of New Bioremediation Systems of Acid Sulfate Soil for Agriculture and Forestry, pp. 57-62. Edited by S. Sasaki \& other authors. Kyoto: Shoukadoh.

Aizawa, T., Nguyen, B. V., Nakajima, M. \& Sunairi, M. (2010). Burkholderia heleia sp. nov., a nitrogen-fixing bacterium isolated from an aquatic plant, Eleocharis dulcis, that grows in highly acidic swamps in actual acid sulfate soil areas of Vietnam. Int J Syst Evol Microbiol 60, 1152-1157.

Baldani, V. L. D., Oliveira, E., Balota, E., Baldani, J. I., Kirchhof, G. \& Döbereiner, J. (1997). Burkholderia brasilensis sp. nov., uma nova espécie de bactéria diazotrófica endofitica. An Acad Bras Cienc 69, 116 (in Portuguese).

Brämer, C. O., Vandamme, P., da Silva, L. F., Gomez, J. G. C. \& Steinbüchel, A. (2001). Burkholderia sacchari sp. nov., a polyhydroxy- 
alkanoate-accumulating bacterium isolated from soil of a sugar-cane plantation in Brazil. Int J Syst Evol Microbiol 51, 1709-1713.

Burris, R. H. (1972). Nitrogen fixation - assay methods and techniques. Methods Enzymol 24, 415-431.

Caballero-Mellado, J., Martínez-Aguilar, L., Paredes-Valdez, G. \& Estrada-de los Santos, P. (2004). Burkholderia unamae sp. nov., an $\mathrm{N}_{2}$-fixing rhizospheric and endophytic species. Int J Syst Evol Microbiol 54, 1165-1172.

Caballero-Mellado, J., Onofre-Lemus, J., Estrada-de los Santos, P. \& Martínez-Aguilar, L. (2007). The tomato rhizosphere, an environment rich in nitrogen-fixing Burkholderia species with capabilities of interest for agriculture and bioremediation. Appl Environ Microbiol 73, 5308-5319.

Chen, W. M., James, E. K., Coenye, T., Chou, J. H., Barrios, E., de Faria, S. M., Elliott, G. N., Sheu, S. Y., Sprent, J. I. \& Vandamme, P. (2006). Burkholderia mimosarum sp. nov., isolated from root nodules of Mimosa spp. from Taiwan and South America. Int J Syst Evol Microbiol 56, 1847-1851.

Chen, W.-M., de Faria, S. M., James, E. K., Elliott, G. N., Lin, K.-Y., Chou, J.-H., Sheu, S.-Y., Cnockaert, M., Sprent, J. I. \& Vandamme, P. (2007). Burkholderia nodosa sp. nov., isolated from root nodules of the woody Brazilian legumes Mimosa bimucronata and Mimosa scabrella. Int J Syst Evol Microbiol 57, 1055-1059.

Ezaki, T., Hashimoto, Y., Takeuchi, N., Yamamoto, H., Liu, S. L., Miura, H., Matsui, K. \& Yabuuchi, E. (1988). Simple genetic method to identify viridans group streptococci by colorimetric dot hybridization and fluorometric hybridization in microdilution wells. $J$ Clin Microbiol 26, 1708-1713.

Ezaki, T., Hashimoto, Y. \& Yabuuchi, E. (1989). Fluorometric deoxyribonucleic acid-deoxyribonucleic acid hybridization in microdilution wells as an alternative to membrane filter hybridization in which radioisotopes are used to determine genetic relatedness among bacterial strains. Int J Syst Bacteriol 39, 224-229.

Felsenstein, J. (1981). Evolutionary trees from DNA sequences: a maximum likelihood approach. J Mol Evol 17, 368-376.

Felsenstein, J. (1985). Confidence limits on phylogenies: an approach using the bootstrap. Evolution 39, 783-791.

Felsenstein, J. (2005). PHYLIP (Phylogeny Inference Package) version 3.65. Distributed by the author. Department of Genome Sciences, University of Washington, Seattle, USA.

Hashidoko, Y., Tada, M., Osaki, M. \& Tahara, S. (2002). Soft gel medium solidified with gellan gum for preliminary screening for root-associating, free-living nitrogen-fixing bacteria inhabiting the rhizoplane of plants. Biosci Biotechnol Biochem 66, 2259-2263.

Jukes, T. H. \& Cantor, C. R. (1969). Evolution of protein molecules. In Mammalian Protein Metabolism, vol. 3, pp. 21-132. Edited by H. N. Munro. New York: Academic Press.

Kimoto, K., Aizawa, T., Urai, M., Nguyen, B. V., Suzuki, K., Nakajima, M. \& Sunairi, M. (2010). Acidocella aluminiidurans sp. nov., an aluminium-tolerant bacterium isolated from Panicum repens grown in a highly acidic swamp in actual acid sulfate soil area of Vietnam. Int J Syst Evol Microbiol 60, 764-768.

Kluge, A. G. \& Farris, J. S. (1969). Quantitative phyletics and the evolution of anurans. Syst Zool 18, 1-32.

Perin, L., Martinez-Aguilar, L., Paredes-Valdez, G., Baldani, J. I., Estrada-de los Santos, P., Reis, V. M. \& Caballero-Mellado, J. (2006). Burkholderia silvatlantica sp. nov., a diazotrophic bacterium associated with sugar cane and maize. Int J Syst Evol Microbiol 56, 1931-1937.

Pot, B., Vandamme, P. \& Kersters, K. (1994). Analysis of electrophoretic whole-organism protein fingerprints. In Chemical Methods in Prokaryotic Systematics (Modern Microbial Methods Series), pp. 493-521. Edited by M. Goodfellow \& A. G. O’Donnell. Chichester: Wiley.

Reis, V. M., Estrada-de los Santos, P., Tenorio-Salgado, S., Vogel, J., Stoffels, M., Guyon, S., Mavingui, P., Baldani, V. L., Schmid, M. \& other authors (2004). Burkholderia tropica sp. nov., a novel nitrogen-fixing, plant-associated bacterium. Int J Syst Evol Microbiol 54, 2155-2162.

Ryu, E. (1938). On the Gram-differentiation of bacteria by the simplest method. J Jpn Soc Vet Sci 17, 31.

Saitou, N. \& Nei, M. (1987). The neighbor-joining method: a new method for reconstructing phylogenetic trees. Mol Biol Evol 4, 406425.

Sasaki, S., Ishii, R., Hasegawa, I., Tokuyama, T., Hanzawa, K., Sumida, H., Ueda, S., Noguchi, A., Matsumoto, R. \& other editors (2008). Development of New Bioremediation Systems of Acid Sulfate Soil for Agriculture and Forestry. Kyoto: Shoukadoh.

Smibert, R. M. \& Krieg, N. R. (1994). Phenotypic characterization. In Methods for General and Molecular Bacteriology, pp. 607-654. Edited by P. Gerhardt, R. G. E. Murray, W. A. Wood \& N. R. Krieg. Washington, DC: American Society for Microbiology.

Stackebrandt, E. \& Goebel, B. (1994). Taxonomic note: a place for DNA-DNA reassociation and $16 \mathrm{~S}$ rRNA sequence analysis in the present species definition in bacteriology. Int J Syst Bacteriol 44, 846849.

Tamura, T. \& Hatano, K. (2001). Phylogenetic analysis of the genus Actinoplanes and transfer of Actinoplanes minutisporangius Ruan et al., 1986 and 'Actinoplanes aurantiacus' to Cryptosporangium minutisporangium comb. nov. and Cryptosporangium aurantiacum sp. nov. Int J Syst Evol Microbiol 51, 2119-2125.

Tamura, T., Nakagaito, Y., Nishii, T., Hasegawa, T., Stackebrandt, E. \& Yokota, A. (1994). A new genus of the order Actinomycetales, Couchioplanes gen. nov., with descriptions of Couchioplanes caeruleus (Horan and Brodsky 1986) comb. nov. and Couchioplanes caeruleus subsp. azureus subsp. nov. Int J Syst Bacteriol 44, 193-203.

Tamura, T., Hayakawa, M. \& Hatano, K. (1999). Sporichthya brevicatena sp. nov. Int J Syst Bacteriol 49, 1779-1784.

Tamura, K., Dudley, J., Nei, M. \& Kumar, S. (2007). MEGA4: molecular evolutionary genetics analysis (MEGA) software version 4.0. Mol Biol Evol 24, 1596-1599.

Thompson, J. D., Gibson, T. J., Plewniak, F., Jeanmougin, F. \& Higgins, D. G. (1997). The CLUSTAL_X windows interface: flexible strategies for multiple sequence alignment aided by quality analysis tools. Nucleic Acids Res 25, 4876-4882.

Valverde, A., Delvasto, P., Peix, A., Velázquez, E., Santa-Regina, I., Ballester, A., Rodríguez-Barrueco, C., Garcia-Balboa, C. \& Igual, J. M. (2006). Burkholderia ferrariae sp. nov., isolated from an iron ore in Brazil. Int J Syst Evol Microbiol 56, 2421-2425.

Vandamme, P., Pot, B., Gillis, M., De Vos, P., Kersters, K. \& Swings, J. (1996). Polyphasic taxonomy, a consensus approach to bacterial systematics. Microbiol Rev 60, 407-438.

Vandamme, P., Goris, J., Chen, W. M., De Vos, P. \& Willems, A. (2002). Burkholderia tuberum sp. nov. and Burkholderia phymatum sp. nov. nodulate the roots of tropical legumes. Syst Appl Microbiol 25, 507-512.

Wayne, L. G., Brenner, D. J., Colwell, R. R., Grimont, P. A. D., Kandler, O., Krichevsky, M. I., Moore, L. H., Moore, W. E. C., Murray, R. G. E. \& other authors (1987). International Committee on Systematic Bacteriology. Report of the ad hoc committee on reconciliation of approaches to bacterial systematics. Int J Syst Bacteriol 37, 463-464.

Weber, O. B., Baldani, V. L. D., Teixeira, K. R. S., Kirchhof, G., Baldani, J. I. \& Döbereiner, J. (1999). Isolation and characterization of diazotrophic bacteria from banana and pineapple plants. Plant Soil 210, 103-113. 
Yabuuchi, E., Kosako, Y., Oyaizu, H., Yano, I., Hotta, H., Hashimoto, Y., Ezaki, T. \& Arakawa, M. (1992). Proposal of Burkholderia gen. nov. and transfer of seven species of the genus Pseudomonas homology group II to the new genus, with the type species Burkholderia cepacia (Palleroni and Holmes 1981) comb. nov. Microbiol Immunol 36, 1251-1275.

Yamada, Y., Takinami-Nakamura, H., Tahara, Y., Oyaizu, H. \& Komagata, K. (1982). The ubiquinone systems in the strains of Pseudomonas species. J Gen Appl Microbiol 28, 7-12.
Yang, H. C., Im, W. T., Kim, K. K., An, D. S. \& Lee, S. T. (2006). Burkholderia terrae sp. nov., isolated from a forest soil. Int J Syst Evol Microbiol 56, 453-457.

Zhang, H., Hanada, S., Shigematsu, T., Shibuya, K., Kamagata, Y., Kanagawa, T. \& Kurane, R. (2000). Burkholderia kururiensis sp. nov., a trichloroethylene (TCE)-degrading bacterium isolated from an aquifer polluted with TCE. Int J Syst Evol Microbiol 50, 743749 . 